\title{
Attenuated Semliki Forest virus for cancer treatment in dogs: safety assessment in two laboratory Beagles
}

\author{
Karoliina P. M. Autio ${ }^{1,2 \dagger}$, Janne J. Ruotsalainen ${ }^{3 \dagger}$, Marjukka O. Anttila ${ }^{4}$, Minna Niittykoski ${ }^{3}$, Matti Waris ${ }^{5}$,
} Akseli Hemminki ${ }^{2}$, Markus J. V. Vähä-Koskela ${ }^{6^{* \dagger}}$ and Ari E. Hinkkanen ${ }^{3+}$

\begin{abstract}
Background: Dogs suffer from spontaneous tumors which may be amenable to therapies developed for human cancer patients, and dogs may serve as large-animal cancer models. A non-pathogenic Semliki Forest virus vector VA7-EGFP previously showed promise in targeting human tumor xenografts in mice, but the oncolytic capacity of the virus in canine cancer cells and the safety of the virus in higher mammals such as dogs, are not known. We therefore assessed the oncolytic potency of VA7-EGFP against canine cancer cells by infectivity and viability assays in two dog solid tumor cell lines. Furthermore we performed a 3-week safety study in two adult Beagles which received a single intravenous injection of $\sim 2 \times 10^{5}$ plaque forming units of parental A7(74) strain.

Results: VA7-EGFP was able to replicate in and kill both canine cancer cell lines tested. No adverse events were observed in either of the two virus-injected adult Beagles and no infective virus could be recovered from any of the biological samples collected over the course of the study. Neutralizing antibodies to Semliki Forest virus became detectable in the dogs at 5 days post infection and remained elevated until study termination.
\end{abstract}

Conclusions: Based on these results, testing of the oncolytic potential of attenuated Semliki Forest virus in canine cancer patients appears feasible.

Keywords: Oncolytic virus, Semliki Forest virus, Canine, Cancer

\section{Background}

Canine tumors resemble human malignancies at cellular, phenotypic, and genomic levels, and dogs may serve as a more realistic cancer model system since their larger body size is more amenable to different surgical techniques and enables better evaluation of biodistribution of drugs and biotherapeutics than laboratory rodent models [1-3]. Because of the unmet therapeutic need in treatment of domestic animal neoplasms and the prospect of using pet cancer patients to narrow the gap to human clinical translation, the development of novel biological therapies to address canine malignancies is justifiable. Such therapies include oncolytic viruses, many of which are capable of infecting also

\footnotetext{
* Correspondence: markus.vaha-koskela@helsinki.fi

†Equal contributors

${ }^{6}$ Institute of Biotechnology, University of Helsinki, P.O. Box 5600014 Helsinki, Finland

Full list of author information is available at the end of the article
}

non-human cells $[4,5]$. Oncolytic viruses replicate preferentially in tumor cells and may potentially spread to distant metastases via the circulation. In addition, virus infection triggers inflammation which under optimal circumstances can break tumor immunosuppression and evoke anti-tumor immune responses [5, 6].

Alphaviruses are enveloped, single-stranded, positive sense RNA viruses of the family Togaviridae, and some of them have shown promising oncolytic potential in preclinical model systems [5, 7]. As animal viruses, alphaviruses may prove ideal candidates for development oncolytic virus therapies for dogs. Moreover, while most alphavirus strains show neurotropism allowing these viruses to pass the blood-brain-barrier to infect cells of the central nervous system (CNS), oncolytic alphaviruses based on nonvirulent strains remain apathogenic and are spontaneously cleared by the immune system [8].

\section{Biomed Central}

(c) 2015 Autio et al. This is an Open Access article distributed under the terms of the Creative Commons Attribution License (http://creativecommons.org/licenses/by/4.0), which permits unrestricted use, distribution, and reproduction in any medium, provided the original work is properly credited. The Creative Commons Public Domain Dedication waiver (http:// creativecommons.org/publicdomain/zero/1.0/) applies to the data made available in this article, unless otherwise stated. 
In previous studies, oncolytic alphavirus VA7, which is based on an attenuated A7(74) strain of Semliki Forest virus (SFV), was capable of eradicating human brain tumors and melanoma xenografts in immunocompromised mice following just a single intravenous injection $[9,10]$, while in other occasions intratumoral administration route was proven superior [11-13]. Oncolytic capacity of attenuated SFV and also other alphaviruses is dependent on the lack of type I interferon responses in the tumor cells $[14,15]$. However, little is known about SFV infections in dogs. In an early study, virulent prototype SFV strain caused neurologic signs of infection in puppies when administered intraperitoneally and intracerebrally but was asymptomatic upon intranasal, intradermal, or intracardial exposure [16]. The oncolytic capacity of SFV or any other alphavirus has not been investigated in canine cancer cells.

We hypothesized that attenuated SFV can infect and kill canine cancer cells and that it can be safely given to dogs intravenously. To test our hypothesis, we infected, as a proof-of-concept, two canine osteosarcoma cell lines (Abrams and D17) in vitro with SFV vector VA7EGFP and assessed virus replication and cell killing. In addition, we performed a minimal safety study in nontumor bearing adult Beagles using $\sim 2 \times 10^{5}$ plaque forming units (PFU) of the unmodified parental virus SFV A7(74) given via intravenous infusion. Our results show, on one hand, that dog tumor cells are able to support replication of oncolytic SFV, and on the other hand, that a limited inoculum of virus does not elicit sideeffects in healthy adult dogs. These results pave the way for clinical translation of attenuated SFV in canine cancer patients.

\section{Results}

\section{Cultured canine cells are permissive to SFV}

We first tested the oncolytic capacity of attenuated SFV in canine cancer cells by infecting two canine osteosarcoma cell lines, Abrams and D17, at various plaqueforming unit (PFU) to cell ratios $(\mathrm{MOI}=$ multiplicity of infection) with our reporter virus VA7-EGFP. Infection was productive in both cell lines, as seen by progressive increase in virus-expressed fluorescent reporter protein, concomitant with progressive cytopathic effects (Fig. 1a) and cell loss (Fig. 1b). Oncolysis was more pronounced in Abrams than in D17 cells at $48 \mathrm{~h}$ (Abrams: MOIs 0 vs $0.01,0,1$ and $1, P<0.001$ in all and D17: $P=0.0053$, 0.008 and 0007 , respectively) (Fig. 1b,c). The rate of oncolysis was comparable to sensitive human glioma cells [10].

\section{Intravenous administration of SFV displayed good safety in adult Beagles}

Two adult female laboratory Beagles were administered by intravenous infusion approximately $2 \times 10^{5}$ PFU of non- recombinant parental SFV A7(74), accounting for a degree of virus inactivation in saline during animal preparation. We kept the injection dose relatively low to assess potential self-amplifying viremia, which is a hallmark of alphavirus infection in susceptible mammalian hosts $[17,18]$. Neither dog showed any clinical signs of infection in any time post infusion. Total white blood cell and differential counts are presented in Fig. 2 and clinical chemistry in Table 1. These results revealed only a minor decrease in serum albumin concentration in dog 23 weeks after virus administration, while low blood glucose was detected in dog 11 week and in $\operatorname{dog} 23$ weeks after virus administration. Further, dog 2 had slightly low sodium concentration three weeks after virus administration. In addition, both dogs had low serum bilirubin, protein, and cholesterol already at baseline compared to the reference values, which remained at similar levels during the study.

\section{Infectious SFV was not detected in the sera, urine, or feces of the dogs}

In order to determine the sensitivity of our virus detection assay in feces, a negative baseline sample (0.1 g) from each dog was spiked with $10^{6}$ PFU and diluted in DMEM. Virus recovery from these samples as shown by plaque assay was $6.25 \times 10^{4} \mathrm{PFU} / 0.1 \mathrm{~g}(6.25 \%$ recovery $)$ and $3.75 \times 10^{5} / 0.1 \mathrm{~g}$ PFU ( $37.5 \%$ recovery) in dog 1 and $\operatorname{dog} 2$, respectively. Thus, using the lower recovery rate, the smallest theoretical amount of feces giving at least one plaque in the assay was $400 \mathrm{PFU} / \mathrm{g}$. Live virus could not be recovered from any of the analyzed serum, urine, or fecal samples. The theoretical detection limit for liquid samples was $25 \mathrm{PFU} / \mathrm{ml}$.

\section{SFV infusion induced high levels of NAbs}

Levels of neutralizing antibodies (NAbs) in serum samples collected before virus injection and 9 and 21 days post infusion were determined by plaque inhibition assay.

NAbs were not present at baseline, while NAb titers of 1250 on day 9 and 250 on day 21, respectively, could be detected in both dogs. Our results thus indicate that both dogs had obtained virus and mounted a humoral immune response in the absence of detectable viremia.

\section{SFV administration did not induce histopathological changes}

Necropsy and histopathology showed no specific findings associated with the virus administration. No virus antigen was detected in any of the organs analyzed.

\section{Discussion}

Oncolytic viruses carry great potential as broadly active cancer therapeutics, as they simultaneously interfere with multiple cell survival signaling pathways and trigger inflammatory responses, which, in turn, may expose the 


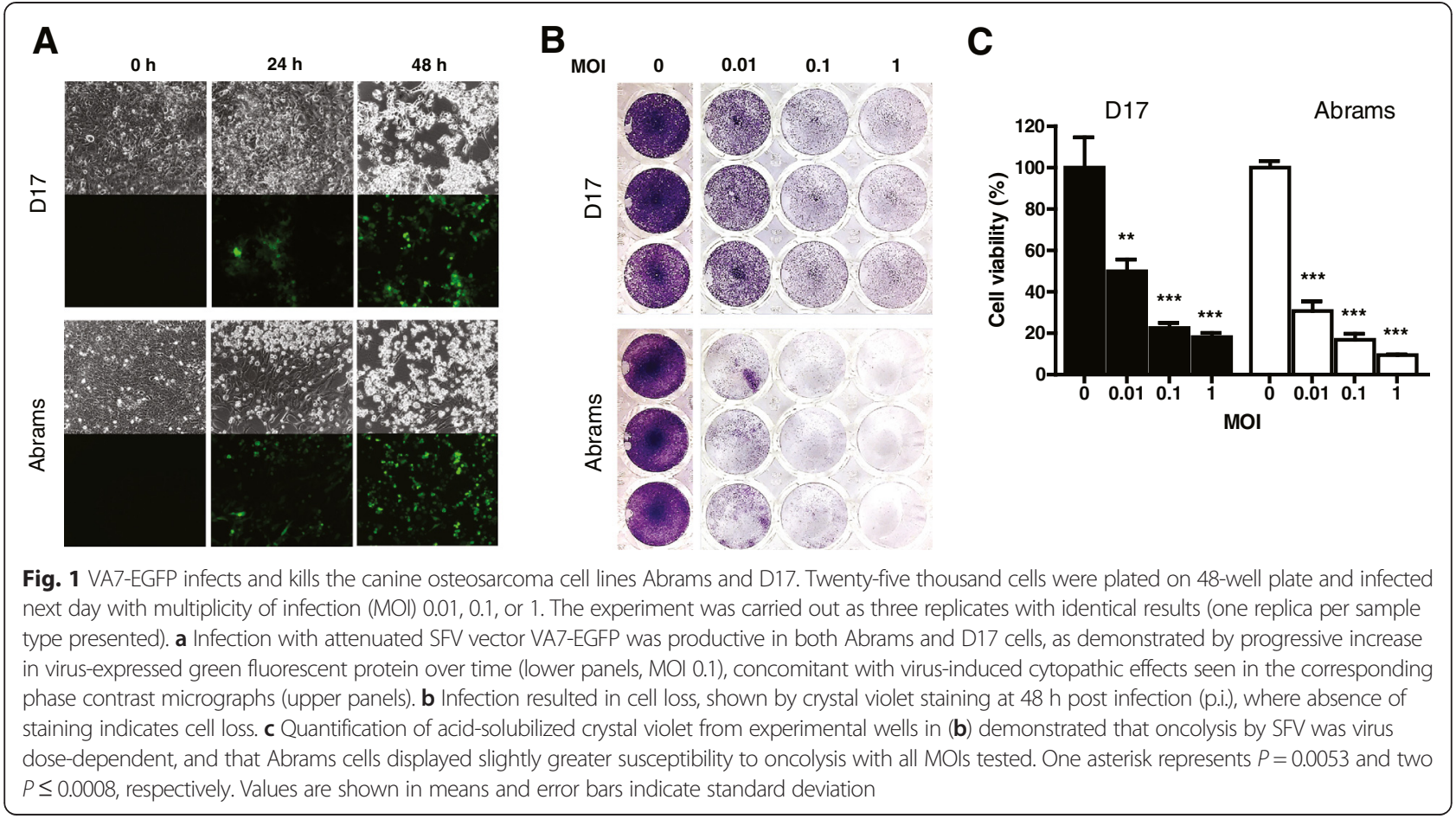

tumors to the immune system. In the present study, we have assessed the potential of a promising oncolytic candidate, attenuated SFV, to target canine cancer. Like most human and rodent cancer cell lines in culture [5], also the two tested dog tumor cell lines were permissive to the virus (Fig. 1). Thus, SFV harbors intrinsic killing capacity against dog tumor cells, a prerequisite for the virus as a potential therapeutic for canine cancer.

While using a broader panel of dog tumor cells may reveal relative degrees of permissiveness to SFV, we have noticed that tumor sensitivity to lysis in vitro may not correlate to therapy efficacy in vivo, rendering extensive in vitro killing assays unwarranted $[15,19,20]$. Stromal cells and physical barriers contribute to restriction of virus spread in vivo, as infection triggers local inflammatory responses principally mediated by type I IFN to which the tumor cells may respond [21]. Paracrine cytokine signaling also serves to control alphavirus infection before further innate and adaptive immune responses have time to take place. However, in normal amplifying hosts, this signaling is sufficiently low to allow for systemic replication [22-24]. Indeed, the attenuated A7(74) used in our study typically induces in susceptible mammalian hosts an asymptomatic viremia of up to $10^{8}$ $\mathrm{PFU} / \mathrm{ml}$, lasting 1-4 days [17, 22, 25-27]. However, we did not detect any infectious virus in the blood, urine, or feces in the experimental dogs at any time post infusion, suggesting that healthy dog tissues are poorly permissive to SFV, resulting in absence of viremia and viral shedding. In theory, the used input dose of approximately $2 \times 10^{5} \mathrm{PFU}$ could have been too low to give rise to detectable viremia. While we cannot completely exclude this possibility, we do not believe it to be the case as very few viral particles are required for productive infection in susceptible host. Depending on the route of inoculation (and to some extent animal species), as little as 3-8 PFU constitute the $50 \%$ protective dose for attenuated SFV strains against lethal SFV strain challenge, with productive replication and $100 \%$ protection reached with 20 PFU administered peripherally $[17,22,28]$. Of note, rabbits, which are significantly larger than mice, still required only $20 \mathrm{PFU}$ to receive $50 \%$ protection against lethal challenge, and while protection against lethal virus challenge may occur in the absence of viremia, it does require productive replication, as defective or inactivated SFV elicits poor protective immune responses compared to live virus $[29,30]$. Therefore, the avirulent SFV strain infection in normal animals is self-regulating and may present as viremia and/or neutralizing anti-SFV antibody response.

The neutralizing antibody response observed in both dogs in the present study indicated productive infection by the attenuated SFV, although no infectious virus was recovered from any blood samples or from the secretions. This is in line with the results from a recent study in healthy dogs injected with vesicular stomatitis virus, where infectious virus could not be detected in blood at any time post injection, but still all dogs developed antiviral antibodies from day 5 onward [31]. In a study with oncolytic adenovirus injected intravenously in healthy dogs infectious virus was not measured, but neutralizing 

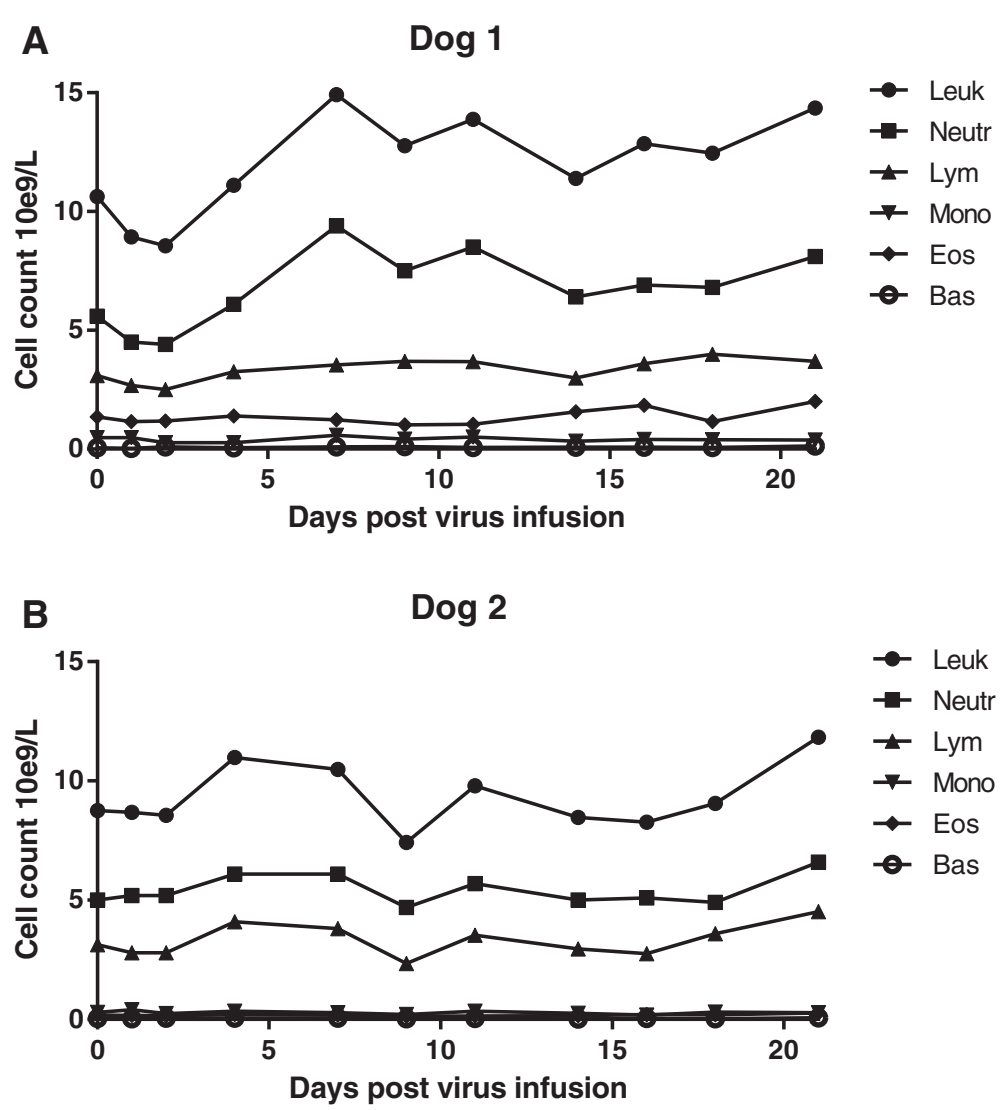

Fig. 2 White blood cell count over time in dog 1 (a) and in $\operatorname{dog} 2$ (b) after Semliki Forest virus infusion. SFV did not cause significant changes in any blood cell counts over the duration of the study. Leuk, leukocytes; Neutr, neutrophils; Mono, monocytes; Lym, lymphocytes; Eos, eosinophils; Bas, basophils

Table 1 Serum clinical chemistry of the Beagles receiving Semliki Forest virus

\begin{tabular}{|c|c|c|c|c|c|c|c|c|c|}
\hline & Dog & 1 & & & Dog & 2 & & & \\
\hline Day & 0 & 7 & 14 & 21 & 0 & 7 & 14 & 21 & Reference value \\
\hline$\overline{A L P}$ & 106 & 103 & 101 & 96 & 103 & 111 & 111 & 107 & $33-215 \mathrm{U} / \mathrm{I}$ \\
\hline ALAT & 34 & 41 & 37 & 34 & 26 & 29 & 31 & 33 & $18-77 \mathrm{U} / \mathrm{I}$ \\
\hline Albumin & 30.6 & 34.9 & 32.8 & 29.9 & 26.2 & 27.3 & 27.4 & 26.3 & $30-41 \mathrm{~g} / \mathrm{l}$ \\
\hline Bilirubin & 1.3 & 1.3 & 1.6 & 1.9 & 1.1 & 0.6 & 1.3 & 1.1 & $2.5-8.5 \mu \mathrm{mol} / \mathrm{l}$ \\
\hline Phosphate & 1.34 & 1.46 & 1.29 & 1.44 & 1.51 & 1.76 & 1.27 & 1.28 & $0.93-2.25 \mathrm{mmol} / \mathrm{l}$ \\
\hline Glucose & 5.2 & 3.5 & 4.2 & 2.9 & 5.7 & 4.7 & 5.1 & 3.6 & $4.0-6.4 \mathrm{mmol} / \mathrm{l}$ \\
\hline Potassium & 4.8 & 4.6 & 4.6 & 4.5 & 5 & 4.9 & 5.1 & 5.3 & $4.2-5.4 \mathrm{mmol} / \mathrm{l}$ \\
\hline Sodium & 148 & 148 & 148 & 147 & 147 & 148 & 149 & 144 & 147-157 mmol/l \\
\hline Calcium & 2.58 & 2.88 & 2.7 & 2.65 & 2.58 & 2.56 & 2.54 & 2.51 & $2.3-3.0 \mathrm{mmol} / \mathrm{l}$ \\
\hline Cholesterol & 3 & 3.8 & 3.3 & 3.1 & 2.5 & 2.6 & 2.4 & 2.1 & $3.7-9.8 \mathrm{mmol} / \mathrm{l}$ \\
\hline Creatinine & 58 & 69 & 67 & 58 & 57 & 62 & 61 & 55 & $57-116 \mu \mathrm{mol} / \mathrm{I}$ \\
\hline Protein & 49 & 57 & 54 & 48 & 45 & 50 & 49 & 45 & $58-77 \mathrm{~g} / \mathrm{l}$ \\
\hline Urea & 4.3 & 5.2 & 5.3 & 8.9 & 6.1 & 4.6 & 4.4 & 7.4 & $2.4-8.8 \mathrm{mmol} / \mathrm{l}$ \\
\hline
\end{tabular}

Bold numbers refer to values that are outside the reference range 
antibodies increased already 4 days after virus administration [32]. So far, the only dog study in which infectious virus has been recovered after injection was with vaccinia virus, but the virus was recovered only from blood samples taken immediately after the intravenous administration [33]. Also in that study, neutralizing antibody responses were demonstrated 2 weeks after virus injection. The relevance of the anti-viral antibodies in oncolytic virotherapy remains incompletely understood, as their presence did not seem to correlate with treatment efficacy for example in patients receiving oncolytic vaccinia- [34, 35] or adenovirus [36-38]. However, the apparent difficulty to detect infectious viruses in dogs suggests rapid absorption of a number of different oncolytic viruses. This may have implications for intravenous delivery or systemic spread of oncolytic viruses in treatment of canine cancer patients. On the other hand, poor permissiveness of normal dog tissues to oncolytic viruses may be beneficial from a safety perspective.

Oncolytic adenovirus has so far showed excellent safety in tumor-bearing [39] and healthy dogs [32], likely owing in part to its restricted species tropism. Oncolytic vaccinia virus was reported to induce mild fever and an apparent epileptiformic seizure in healthy Beagles [33]. Several mild to moderate adverse events and one severe liver toxicity resulting in euthanasia were reported in healthy Beagle dogs receiving high-dose oncolytic vesicular stomatitis virus [31]. Unlike vesicular stomatitis virus, attenuated SFV can be safely injected intracranially in adult animals, where virus replication remains confined to mainly perivascular foci $[11,24,40]$. CD8+ Tcell-mediated elimination of the virus may in certain mouse strains be associated with demyelination [41-43], but such effects are transient and without apparent clinical symptoms [44]. Notably, we did not see any pathological changes or cellular infiltrates in the dog brains post-mortem.

In light of the poor capacity of SFV to replicate in dogs upon intravenous injection, clinical application of the virus in canine cancer patients would most likely entail intratumoral virus injections ensuring successful delivery of the virus into the tumor mass. This route has occasionally proven to be therapeutically superior over systemic administration even in susceptible hosts [11, 13]. Theoretically, SFV could amplify in tumors of canine cancer patients, disseminate into the blood and then be spread during the viremia by Aedes mosquitos endemic in the tropical areas [45]. Hence, viremia and shedding parameters should be established separately for canine cancer patients in the future.

\section{Conclusions}

We report here the first proof-of-principle data for Semliki Forest virus as a candidate oncolytic agent in dogs.
As our results demonstrate, live attenuated SFV VA7EGFP was able to replicate and kill canine osteosarcoma cells in vitro, and parental A7(74) strain was safe causing no visible symptoms or distress in the laboratory Beagles. No virus could be detected in any of the organs, blood or secretions analyzed. Our findings support proceeding with SFV mediated oncolytic virotherapy to first stage clinical studies in canine cancer patients.

\section{Methods}

\section{Virus and cell lines}

Generation of the plaque-purified replication competent, attenuated A7(74) strain of SFV, kindly donated by Dr. R. E. Shope at the Yale Arbovirus Research Unit (Yale School of Medicine, CT, USA), has been described previously [17]. Generation of replication competent, attenuated VA7-EGFP expressing enhanced green fluorescent protein used in the in vitro studies has been also described earlier [8]. Viruses were amplified in BHK-21 baby hamster kidney cells (obtained from ATCC; Manassas, VA, USA) grown in high glucose ( $4.5 \mathrm{~g} / \mathrm{l})$ Dulbecco's modified Eagles's medium (DMEM; D6046, Sigma-Aldrich, St Louis, MO, USA) supplemented with $5 \%$ fetal bovine serum (FCS), $2 \mathrm{mM}$ L-glutamine, penicillin-streptomycin and $20 \mathrm{mM}$ HEPES. The virus containing supernatant was collected $24 \mathrm{~h}$ post infection (p.i)., cell debris spinned down, and the supernatant sterile-filtered using $0.2 \mu \mathrm{m}$ filter before freezing the virus in $-70^{\circ} \mathrm{C}$ in work aliquots.

Two canine osteosarcoma cell lines, Abrams (kindly donated by Dr. D. Vail, University of Wisconsin-Madison, USA,) and D17 (kindly donated by Dr. R. Alemany, Catalan Institute of Oncology, Barcelona, Spain) [46], were tested mycoplasma- free and grown in DMEM with $1 \mathrm{~g} / \mathrm{l}$ glucose (D6046, Sigma Aldrich) supplemented with $1 \%$ L-glutamine and $1 \%$ penicillin-streptomycin. The culture medium was supplemented with $5 \%$ FBS for Abrams and $10 \%$ FBS for D17. Vero cells (obtained from ATCC) were grown in DMEM with $1 \mathrm{~g} / \mathrm{l}$ glucose (D6046, Sigma Aldrich) supplemented with $25 \mathrm{mM}$ HEPES, 1 \% L-glutamine, 5 \% FBS, and $1 \%$ penicillin-streptomycin.

\section{Infection of canine cell lines}

Abrams and D17 cells were plated on 48-well plates at a density of 25,000 cells/well. The next day, the cells were infected with VA7-EGFP at MOI of 0.01, 0.1, and 1. Growth medium was used as sham treatment and all samples were prepared as triplicate with identical results. Virus infection was monitored by fluorescence microscopy and cytopathic effect was evaluated by phase contrast microscopy (Zeiss Axio Observer Z1 microscope, Zeiss, Oberkochen, Germany) 24 and 48 h p.i. Finally, crystal violet staining was performed to reveal cytopathic effect at the final time point of $48 \mathrm{~h}$ p.i. and stained plates were imaged with digital camera. For quantification of cell 
viability, crystal violet from stained wells was dissolved in $250 \mu \mathrm{l} 10 \%$ acetic acid for $20 \mathrm{~min}$ in room temperature in a shaker. Samples from dissolved dye were transferred to 96-well plate and absorbance was measured at $595 \mathrm{~nm}$ wavelength with plate reader (VICTOR2, PerkinElmer, Waltham, MA, USA).

\section{Dogs}

Two healthy adult female HsdRcc:DOBE Beagle dogs (Harlan Laboratories, Gannat, France) were infected with A7(74) strain of SFV. Both dogs were 1 year old retired breeding females. The dogs were housed together in standard conditions, fed twice daily, and given water ad libitum. The experiment was approved by the National Animal Experiment Board of the Regional State Administrative Agency of Southern Finland (ESAVI/3231/ 04.10.07/2013). Dog 1 weighed $6.7 \mathrm{~kg}$ and dog 2, $12.9 \mathrm{~kg}$.

\section{Study design}

Before virus administration, an intravenous catheter was placed into the cephalic vein and $10 \mathrm{ml}$ of sterile saline was administered to ensure vein access. As SFV is $\mathrm{pH}$-sensitive and could potentially suffer from inactivation in physiological saline which lacks buffering capacity, we chose to inject 1 million PFU of the virus in order to expose the dogs to a minimally infective dose (see Discussion). Virus was diluted in $50 \mathrm{ml}$ of saline (0.9 \% Sodium Chloride Irrigation, Baxter, Norfolk, UK) and kept on ice until given to the dogs via intravenous infusion over $15 \mathrm{~min}(200 \mathrm{ml} / \mathrm{h})$. The infusion line ran through tempered water bath $\left(37^{\circ} \mathrm{C}\right)$ before entering the vein. After virus administration, the virus-saline bag and infusion line were flushed with $25 \mathrm{ml}$ of saline at the same infusion rate to ensure that the dogs received the entire dose of virus. Altogether the infusions lasted for approximately $23 \mathrm{~min}$.

The dogs were monitored for adverse events according to the Veterinary Cooperative Oncology Group - Common Terminology Criteria for Adverse Events (VCOG-
CTCAE) v1.1 [47]. Attitude, respiratory rate, heart rate, color of mucous membranes, capillary refill time, rectal temperature, and blood pressure were monitored before virus administration, then 15 and $30 \mathrm{~min}$, and 1, 2, 4, 8, 11 , and $24 \mathrm{~h}$ after the initiation of virus infusion. In addition, the dogs were monitored for swelling, itching, and vomiting, which are the most common signs of hypersensitivity in this species. After $24 \mathrm{~h}$, attitude and appetite were monitored twice daily, and weight, respiratory rate, color of mucous membranes, capillary refill time, and rectal temperature once daily. The dogs were euthanized 3 weeks after virus infusions, and had full necropsy.

\section{Sample collection}

The sample collection schedule is shown in Fig. 3. Four milliliters of blood were collected into serum tubes for virus detection from jugular, cephalic, or saphenous vein before and 2, 4, and $22 \mathrm{~h}$ and 2, 4, 7, 9, 14, and 21 days after virus infusion. Urine $(5 \mathrm{ml})$ was collected by cystocentesis and feces (10-15 g) were collected rectally. Serum was separated after $20 \mathrm{~min}$ incubation in room temperature by centrifuging $10 \mathrm{~min} 2400 \mathrm{~g}$. It was then frozen first at $-18{ }^{\circ} \mathrm{C}$ and transferred the same day into $-80{ }^{\circ} \mathrm{C}$ until virus titer analysis. Urine and fecal samples were frozen and stored according to the same protocol.

One milliliter blood was collected for hematology before, and 1, 2, and 4 days after virus administration and then three times weekly. In addition, $6 \mathrm{ml}$ of blood were collected into serum tube for clinical chemistry and the assessment of SFV antibody titers before virus infusion and then, 9-21 days after virus administration. Serum was separated as described earlier. Hematological parameters were determined by an automated analyzer (ADVIA 2120i Hematology System, Siemens Healthcare Diagnostics Inc., Tarrytown, NY, USA) and serum was assayed by a clinical chemistry analyzer (Konelab 30i, ThermoFisher Scientific, Vantaa, Finland). Urinalysis was done once a week by dipstic (Multistix ${ }^{\circledR} 10$ SG, Siemens Healthcare Diagnostics Inc.) read with automated reading device (Clinitek Status,

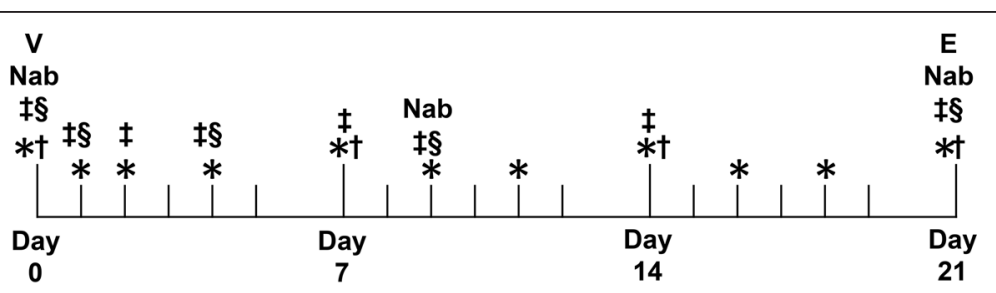

V, Virus administration; Nab, Neutralizing antibodies; $*$, Complete blood count; $\mathrm{t}$, Chemistry panel and urinalysis; ¥, Blood for virus detection; §, Urine and feces for virus detection; E, Euthanasia

Fig. 3 Study chart and sample collection for safety evaluation of Semliki Forest virus in two Beagle dogs. V Virus administration, Nab Neutralizing antibodies, * Complete blood count, † Chemistry panel and urinalysis, ‡ Blood for virus detection, $\S$ Urine and feces for virus detecttion, E Euthanasia 
Siemens Healthcare Diagnostics Inc.) Specific gravity was determined by refractometry, and a standard volume $(0.5 \mathrm{ml})$ of urine sediment was examined under a light microscope using $10 \times$ and $40 \times$ objectives after centrifugation $(5 \mathrm{~min} 600 \mathrm{~g}$ ). Urine protein-creatinine ratio was measured by a clinical chemistry analyzer (Konelab 30i). Samples for SFV antibody titer were frozen first at $-18{ }^{\circ} \mathrm{C}$ and transferred the same day into $-80{ }^{\circ} \mathrm{C}$ until analysis. Hematology, chemistry panel, and urinalysis were analyzed the day they were collected.

\section{Virus titration}

Sera obtained from the dogs were titered for SFV A7(74) on Vero cells according to Ruotsalainen et al. [15]. Serial dilutions of samples were prepared in cold medium. Stock A7(74) virus was used as a positive assay control. In order to exclude the possibility that the virus had been inactivated during infusion procedure, we simulated the conditions of the virus administration protocol by keeping the A7(74) virus -containing sterile saline infusion bag on ice for $3 \mathrm{~h} 25 \mathrm{~min}$. This was the maximum time from the virus infusion preparation, performed in a separate BLS2 facility, until the end of the virus infusion. We then keept the virus-saline mixture for $1 \mathrm{~min}$ in a $37^{\circ} \mathrm{C}$ water bath, and finally collected and titered the viral solution by plaque assay in Vero cells. The protocol for virus titration from urine and feces samples was modified from Buonacurio et al. [48]. Urine samples were diluted 1:10 and 1:100 in DMEM with $1 \mathrm{~g} /$ 1 glucose and virus titration was performed on Vero cells as for the sera. Before virus titration from fecal samples $10 \times(\mathrm{w} / \mathrm{v})$ of DMEM was mixed with the feces $(0.1-$ $0.2 \mathrm{~g}$ ), and centrifuged at $3000 \mathrm{~g}$ for $10 \mathrm{~min}$ at $4{ }^{\circ} \mathrm{C}$. The supernatant was sterile-filtered using $0.22 \mu \mathrm{m}$ polyethersulfone membrane syringe filter (Syringe Filter, Porvair Science, Leatherhead, UK) and diluted in growth medium 1:10 and 1:100 for titration purposes. Recovery controls were prepared for fecal samples by adding $10^{6} \mathrm{PFU}$ of SFV A7(74) per $0.1 \mathrm{~g}$ of baseline fecal samples of the two dogs diluted in $10 \times(\mathrm{w} / \mathrm{v})$ amount of medium. The virus-fecesmedium mixtures were then vortexed, sterile filtered, serial diluted (from $10^{-1}$ to $10^{-6}$ ) in growth medium, and titered as described above.

\section{Neutralizing antibodies}

NAbs were measured from the serum samples collected on baseline, and 9 and 21 days after the virus infusion according to Ruotsalainen et al. [19]. Briefly, titering of NAbs was performed on Vero cells plated on 12-well plates. The serum samples were diluted 1/2, 1/5, 1/25, 1/125, 1/625 and 1/3125 in DMEM, and the dilutions mixed 1:1 $(100 \mu \mathrm{l}: 100 \mu \mathrm{l})$ with A7(74) solution containing $50 \mathrm{PFU}$ of virus. The mixture was incubated on ice for approximately 30 min before plaque titering on Vero cells seeded on 12- well plates as duplicates. Pure medium served as a negative control, and polyclonal rabbit anti-SFV antibody in DMEM as a positive control. Fluorescence was monitored by fluorescence microscope (Zeiss Axio Observer Z1 microscope). The neutralizing antibody titer was defined as the greatest dilution of virus completely preventing plaque formation.

\section{Necropsy}

Necropsy and histopathological examination were performed by a board-certified pathologist (MOA). Representative samples of all selected organs (Additional file 1) were collected and fixed in $10 \%$ buffered formalin. All samples were dehydrated, embedded in paraffin, sectioned, and stained with hematoxylin and eosin. In addition, tissue samples obtained from organs previously known to harbor SFV in mice $[9,49]$ (brain hippocampus, cortex, corpus callosum, cerebellum and pons; kidneys; liver; lymph nodes: mandibular and mesenteric; skeletal muscle; spleen; cervical spinal cord) were stained by polyclonal rabbit anti-SFV antibody using Vectastain $\mathrm{ABC}$ kit (Vector Laboratories, Burlingame, CA, USA) followed by hematoxylin counterstain. SFV envelope antigen-positive mouse brain was used as a control. Sections were examined under microscope via $40 \times$ and $10 \times$ objectives.

\section{Statistical analysis}

Cell viability in percentages was counted from absorbance using formula: (A595(sample) / mean A595(uninfected sample) $) \times 100$. The data was plotted and analyzed with GraphPad Prism (GraphPad Software, Inc. La Jolla, CA, USA). Statistical analysis was done using unpaired, twotailed $t$-test and $P<0.01$ was considered significant.

\section{Additional file}

Additional file 1: Tissue list for histopathology collection from the dogs receiving Semliki Forest virus (SFV). (DOCX 14 kb)

\section{Abbreviations}

DMEM: Dulbecco's modified Eagles's medium; EGFP: Enhanced green fluorescent protein; FBS: Fetal bovine serum; HEPES: 4-(2-hydroxyethyl)-1piperazineethanesulfonic acid; MOI: Multiplicity of infection;

NAbs: Neutralizing antibodies; p.i.: post infection; PFU: Plaque forming units; SFV: Semliki Forest virus.

\section{Competing interest}

$\mathrm{AH}$ is shareholder of Oncos Therapeutics Ltd and employee and shareholder of TILT Biotherapeutics Ltd.

\section{Authors' contributions}

KPMA performed the animal study, JJR the preclinical studies and analyzed viral samples and both contributed to manuscript preparation equally. MOA performed the necropsies and analyzed the tissue samples. MN carried out immunohistochemistry. MW and $\mathrm{AH}$ engaged in the design and coordination of the study. MJW-K and AEH participated in the design and coordination of the study and helped in preparation of the manuscript. All authors read and approved the final manuscript. 


\section{Acknowledgements}

The study was supported in part by Aniwel Graduate School University of Helsinki (KPMA), and Medicinska Understödsföreningen Liv och Hälsa, Cancer Center of Eastern Finland and Emil Aaltonen Foundation (JJR, MN, AEH). We wish to express our gratitude to Miika Martikainen for the help in the in vitro cytotoxicity assays.

\section{Author details \\ ${ }^{1}$ Department of Equine and Small Animal Medicine, Faculty of Veterinary Medicine, University of Helsinki, P.O. Box 5700014 Helsinki, Finland. ${ }^{2}$ Cancer Gene Therapy Group, Department of Pathology and Transplantation Laboratory, Haartman Institute, University of Helsinki, P.O. Box 2100014 Helsinki, Finland. ${ }^{3}$ A. I. Virtanen Institute for Molecular Sciences, Biotechnology and Molecular Medicine, University of Eastern Finland, P.O. Box 162770211 Kuopio, Finland. ${ }^{4}$ Finnish Food Safety Authority Evira, Pathology Unit, Mustialankatu 3, 00790 Helsinki, Finland. ${ }^{5}$ Department of Virology, University of Turku, 20014 Turku, Finland. Institute of Biotechnology, University of Helsinki, P.O. Box 5600014 Helsinki, Finland.}

Received: 25 February 2015 Accepted: 20 July 2015

Published online: 28 July 2015

\section{References}

1. Gordon I, Paoloni M, Mazcko C, Khanna C. The Comparative Oncology Trials Consortium: using spontaneously occurring cancers in dogs to inform the cancer drug development pathway. PLoS Med. 2009;6(10), e1000161.

2. Ranieri G, Gadaleta CD, Patruno R, Zizzo N, Daidone MG, Hansson MG, et al. A model of study for human cancer: Spontaneous occurring tumors in dogs. Biological features and translation for new anticancer therapies. Crit Rev Oncol Hematol. 2013;88(1):187-97.

3. Cekanova M, Rathore K. Animal models and therapeutic molecular targets of cancer: utility and limitations. Drug Des Devel Ther. 2014;8:1911-21.

4. Patil SS, Gentschev I, Nolte I, Ogilvie G, Szalay AA: Oncolytic virotherapy in veterinary medicine: current status and future prospects for canine patients. J Transl Med 2012, 10:3-5876-10-3.

5. Vaha-Koskela MJ, Heikkila JE, Hinkkanen AE. Oncolytic viruses in cancer therapy. Cancer Lett. 2007;254(2):178-216.

6. Elsedawy NB, Russell SJ. Oncolytic vaccines. Expert Rev Vaccines. 2013;12(10):1155-72.

7. Quetglas JI, Ruiz-Guillen M, Aranda A, Casales E, Bezunartea J, Smerdou C. Alphavirus vectors for cancer therapy. Virus Res. 2010;153(2):179-96.

8. Vaha-Koskela MJ, Tuittila MT, Nygardas PT, Nyman JK, Ehrengruber MU, Renggli $\mathrm{M}$, et al. A novel neurotropic expression vector based on the avirulent A7(74) strain of Semliki Forest virus. J Neurovirol. 2003;9(1):1-15.

9. Vaha-Koskela MJ, Kallio JP, Jansson LC, Heikkila JE, Zakhartchenko VA Kallajoki MA, et al. Oncolytic capacity of attenuated replicative semliki forest virus in human melanoma xenografts in severe combined immunodeficient mice. Cancer Res. 2006;66(14):7185-94.

10. Heikkila JE, Vaha-Koskela MJ, Ruotsalainen JJ, Martikainen MW, Stanford MM, McCart JA, et al. Intravenously administered alphavirus vector VA7 eradicates orthotopic human glioma xenografts in nude mice. PLoS One. 2010;5(1), e8603.

11. Maatta AM, Liimatainen T, Wahlfors T, Wirth T, Vaha-Koskela M, Jansson L, et al. Evaluation of cancer virotherapy with attenuated replicative Semliki forest virus in different rodent tumor models. Int J Cancer. 2007;121(4):863-70.

12. Ketola A, Hinkkanen A, Yongabi F, Furu P, Maatta AM, Liimatainen T, et al. Oncolytic Semliki forest virus vector as a novel candidate against unresectable osteosarcoma. Cancer Res. 2008;68(20):8342-50.

13. Maatta AM, Makinen K, Ketola A, Liimatainen T, Yongabi FN, Vaha-Koskela M, et al. Replication competent Semliki Forest virus prolongs survival in experimental lung cancer. Int J Cancer. 2008;123(7):1704-11.

14. Lin Y, Zhang H, Liang J, Li K, Zhu W, Fu L, et al. Identification and characterization of alphavirus $\mathrm{M} 1$ as a selective oncolytic virus targeting ZAP-defective human cancers. Proc Natl Acad Sci USA. 2014;111(42):E4504-12.

15. Ruotsalainen JJ, Kaikkonen MU, Niittykoski M, Martikainen MW, Lemay CG, Cox J, et al. Clonal variation in interferon response determines the outcome of oncolytic virotherapy in mouse CT26 colon carcinoma model. Gene Ther. 2015;22:65-75

16. Reagan RL, Strand N, Brueckner AL. Bwamba fever virus and Semliki Forest virus in young dogs. Proc Soc Exp Biol Med. 1953;82(4):642-3.
17. Bradish CJ, Allner K, Maber HB. The virulence of original and derived strains of Semliki forest virus for mice, guinea-pigs and rabbits. J Gen Virol. 1971;12(2):141-60

18. Smith GL. Rapid spreading and immune evasion by vaccinia virus. Adv Exp Med Biol. 2014;808:65-76.

19. Ruotsalainen J, Martikainen M, Niittykoski M, Huhtala T, Aaltonen T, Heikkila J, et al. Interferon-beta sensitivity of tumor cells correlates with poor response to VA7 virotherapy in mouse glioma models. Mol Ther. 2012;20(8):1529-39.

20. Vaha-Koskela MJ, Le Boeuf F, Lemay C, De Silva N, Diallo JS, Cox J, et al. Resistance to two heterologous neurotropic oncolytic viruses, Semliki Forest virus and vaccinia virus, in experimental glioma. J Virol. 2013;87(4):2363-6.

21. Vähä-Koskela M, Hinkkanen $\mathrm{A}$. Tumor restrictions to oncolytic virus Biomedicines. 2014;2(2):163-94.

22. Bradish CJ, Allner K. The early responses of mice to respiratory or intraperitoneal infection by defined virulent and avirulent strains of Semliki forest virus. J Gen Virol. 1972;15(3):205-18.

23. Muller U, Steinhoff U, Reis LF, Hemmi S, Pavlovic J, Zinkernagel RM, et al. Functional role of type I and type II interferons in antiviral defense. Science. 1994;264(5167):1918-21.

24. Fragkoudis R, Breakwell L, McKimmie C, Boyd A, Barry G, Kohl A, et al. The type I interferon system protects mice from Semliki Forest virus by preventing widespread virus dissemination in extraneural tissues, but does not mediate the restricted replication of avirulent virus in central nervous system neurons. J Gen Virol. 2007;88(Pt 12):3373-84.

25. Fleming P. Age-dependent and strain-related differences of virulence of Semliki Forest virus in mice. J Gen Virol. 1977;37(1):93-105.

26. Jagelman S, Suckling AJ, Webb HE, Bowen FT. The pathogenesis of avirulent Semliki Forest virus infections in athymic nude mice. J Gen Virol. 1978;41(3):599-607.

27. Fazakerley JK, Pathak S, Scallan M, Amor S, Dyson H. Replication of the A7(74) strain of Semliki Forest virus is restricted in neurons. Virology. 1993;195(2):627-37.

28. Bradish CJ, Allner K, Maber HB. Infection, interaction and the expression of virulence by defined strains of Semliki forest virus. J Gen Virol. 1972;16(3):359-72.

29. Barrett AD, Dimmock NJ. Modulation of Semliki Forest virus-induced infection of mice by defective-interfering virus. J Infect Dis. 1984;150(1):98-104.

30. Kraaijeveld CA, Schilham M, Jansen J, Benaissa-Trouw B, Harmsen M, van Houte AJ, et al. The effect of liposomal charge on the neutralizing antibody response against inactivated encephalomyocarditis and Semliki Forest viruses. Clin Exp Immunol. 1984;56(3):509-14

31. LeBlanc AK, Naik S, Galyon GD, Jenks N, Steele M, Peng KW, et al. Safety studies on intravenous administration of oncolytic recombinant vesicular stomatitis virus in purpose-bred beagle dogs. Hum Gene Ther Clin Dev. 2013;24(4):174-81

32. Smith BF, Curiel DT, Ternovoi W, Borovjagin AV, Baker HJ, Cox N, et al. Administration of a conditionally replicative oncolytic canine adenovirus in normal dogs. Cancer Biother Radiopharm. 2006;21(6):601-6.

33. Autio K, Knuuttila A, Kipar A, Pesonen S, Guse K, Parviainen S, et al. Safety and biodistribution of a double-deleted oncolytic vaccinia virus encoding CD40 ligand in laboratory Beagles. MTO. 2014;1:14002.

34. Mastrangelo MJ, Maguire Jr HC, Eisenlohr LC, Laughlin CE, Monken CE, McCue PA, et al. Intratumoral recombinant GM-CSF-encoding virus as gene therapy in patients with cutaneous melanoma. Cancer Gene Ther. 1999;6(5):409-22

35. Park BH, Hwang T, Liu TC, Sze DY, Kim JS, Kwon HC, et al. Use of a targeted oncolytic poxvirus, JX-594, in patients with refractory primary or metastatic liver cancer: a phase I trial. Lancet Oncol. 2008;9(6):533-42.

36. Sarkioja M, Pesonen S, Raki M, Hakkarainen T, Salo J, Ahonen MT, et al. Changing the adenovirus fiber for retaining gene delivery efficacy in the presence of neutralizing antibodies. Gene Ther. 2008;15(12):921-9.

37. Pesonen S, Nokisalmi P, Escutenaire S, Sarkioja M, Raki M, Cerullo V, et al. Prolonged systemic circulation of chimeric oncolytic adenovirus Ad5/3-Cox2LD24 in patients with metastatic and refractory solid tumors. Gene Ther. 2010;17(7):892-904.

38. Westphal M, Yla-Herttuala S, Martin J, Warnke P, Menei P, Eckland D, et al. Adenovirus-mediated gene therapy with sitimagene ceradenovec followed by intravenous ganciclovir for patients with operable high-grade glioma 
(ASPECT): a randomised, open-label, phase 3 trial. Lancet Oncol. 2013;14(9):823-33

39. Laborda E, Puig-Saus C, Rodriguez-Garcia A, Moreno R, Cascallo M, Pastor J, et al. A pRb-responsive, RGD-modified, and hyaluronidase-armed canine oncolytic adenovirus for application in veterinary oncology. Mol Ther. 2014;22:986-98.

40. Fragkoudis R, Tamberg N, Siu R, Kiiver K, Kohl A, Merits A, et al. Neurons and oligodendrocytes in the mouse brain differ in their ability to replicate Semliki Forest virus. J Neurovirol. 2009;15(1):57-70.

41. Suckling AJ, Pathak S, Jagelman S, Webb HE. Virus-associated demyelination. A model using avirulent Semliki Forest virus infection of mice. J Neurol Sci. 1978;39(1):147-54.

42. Kelly WR, Blakemore WF, Jagelman S, Webb HE. Demyelination induced in mice by avirulent Semliki Forest virus. II. An ultrastructural study of focal demyelination in the brain. Neuropathol Appl Neurobiol. 1982;8(1):43-53.

43. Subak-Sharpe I, Dyson H, Fazakerley J. In vivo depletion of CD8+ T cells prevents lesions of demyelination in Semliki Forest virus infection. J Virol. 1993;67(12):7629-33.

44. Mokhtarian F, Huan CM, Roman C, Raine CS. Semliki Forest virus-induced demyelination and remyelination-involvement of $B$ cells and anti-myelin antibodies. J Neuroimmunol. 2003;137(1-2):19-31.

45. Mathiot CC, Grimaud G, Garry P, Bouquety JC, Mada A, Daguisy AM, et al. An outbreak of human Semliki Forest virus infections in Central African Republic. Am J Trop Med Hyg. 1990:42(4):386-93.

46. Legare ME, Bush J, Ashley AK, Kato T, Hanneman WH. Cellular and phenotypic characterization of canine osteosarcoma cell lines. J Cancer. 2011;2:262-70

47. Veterinary cooperative oncology group: Veterinary cooperative oncology group - common terminology criteria for adverse events (VCOG-CTCAE) following chemotherapy or biological antineoplastic therapy in dogs and cats v1.1. Vet Comp Oncol 2011, 1-30.

48. Buonagurio DA, Coleman JW, Patibandla SA, Prabhakar BS, Tatem JM. Direct detection of Sabin poliovirus vaccine strains in stool specimens of first-dose vaccinees by a sensitive reverse transcription-PCR method. J Clin Microbiol. 1999:37(2):283-9.

49. Smithburn KC, Haddow AJ, Mahaffy AF. A neurotropic virus isolated from Aedes mosquitoes caught in the Semliki forest. Am J Trop Med Hyg. 1946;26:189-208.

\section{Submit your next manuscript to BioMed Central and take full advantage of:}

- Convenient online submission

- Thorough peer review

- No space constraints or color figure charges

- Immediate publication on acceptance

- Inclusion in PubMed, CAS, Scopus and Google Scholar

- Research which is freely available for redistribution 